\title{
UPITNIK EMOCIONALNE KOMPETENTNOSTI ZA DJECU (UEK-D) - PRELIMINARNI REZULTATI PRILAGODBE I VALIDACIJE
}

\author{
Mia Stupin \\ Odsjek za psihologiju, Filozofski fakultet Sveučilišta u Rijeci \\ Sveučilišna avenija 4, 51000 Rijeka \\ mstupin@ffri.hr \\ Tamara Mohorić \\ Odsjek za psihologiju, Filozofski fakultet Sveučilišta u Rijeci \\ Sveučilišna avenija 4, 51000 Rijeka \\ tmohoric@ffri.hr \\ Ivana Ilijašić Veršić \\ Consortium of Social Science Data Archives (CESSDA ERIC) \\ Parkveien 20, 5007, Bergen, Norveška \\ ivana.versic@cessda.eu
}

\begin{abstract}
Sažetak
Upitnik emocionalne kompetentnosti (UEK-45, Takšić, 1998, 2002) temelji se na hijerarhijskom modelu emocionalne inteligencije (EI), koji EI definira kao sposobnost percepcije i izražavanja emocija, integracije emocija u procese mišljenja, razumijevanja emocija te sposobnost upravljanja emocijama. Do sada je korišten u velikom broju istraživanja i preveden na više od 10 svjetskih jezika, međutim, ne postoji prilagođena i provjerena verzija upitnika koja bi bila primjerena djeci osnovnoškolske dobi. S obzirom na važnost istraživanja emocionalnih aspekata dječjeg razvoja, nužno je imati provjerene mjere na temelju kojih se mogu donositi valjani zaključci. Ovo je istraživanje prvi korak u prilagodbi Upitnika emocionalne kompetentnosti za djecu. U istraživanju je sudjelovao 171 ispitanik, učenici viših razreda osnovne škole, u dobi od 11 do 15 godina te 277 ispitanika 5. i 6. razreda, iz osnovnih škola iz Rijeke i Rovinja. Upitnik emocionalne kompetentnosti za djecu zadržao je originalnu trofaktorsku strukturu uz dobru sadržajnu valjanost i pouzdanost (koja je jedino nešto niža za podljestvicu Regulacije i upravljanja emocijama). Dobivene su očekivane umjerene korelacije s osobinama ličnosti iz modela velikih pet. Što se tiče kriterijske valjanosti, emocionalna kompetentnost značajno je povezana s altruističnim ponašanjem te sa školskim uspjehom (iako vrlo nisko), a nije dobivena povezanost s agresivnim ponašanjem iako se prema dosadašnjim istraživanjima ona očekuje. Upitnik je jezično i brojem čestica prilagođen djeci. U daljnjim istraživanjima potrebno je sadržajno prilagoditi upitnik kako bi se obuhvatilo što više aspekata emocionalne inteligencije te dodatno provjeriti strukturu upitnika.
\end{abstract}

Ključne riječi: emocionalna kompetentnost, UEK-D, rana adolescencija, osobine ličnosti velikih pet 


\section{UVOD}

Emocionalna kompetentnost kompleksan je konstrukt koji uključuje više različitih, iako međusobno povezanih vještina, poput procjene, izražavanja i razumijevanja emocija (Saarni, 1999). Upravo te sposobnosti obuhvaća i emocionalna inteligencija, koja se najčešće i definira kao sposobnost percepcije i izražavanja emocija, integracije emocija u procese mišljenja, razumijevanje emocija te sposobnost upravljanja emocijama (engl. ability EI; Mayer i Salovey, 1997). Osim kao sposobnost, emocionalna inteligencija definira se i kao crta (engl. trait EI), i u tom slučaju odnosi se na različite samoprocijenjene osobine vezane uz emocije te se nalazi na nižim razinama hijerarhijskih modela ličnosti (Petrides, Pita i Kokkinaki, 2007). Hijerarhijski model Mayera i Saloveya (1997) definira EI kroz 4 grane, odnosno sposobnosti, čija se složenost povećava od prve prema četvrtoj grani. Na najnižoj razini (grana 1) EI je sposobnost percepcije i izražavanja emocija. Grana 2 uključuje integraciju emocija u procese mišljenja, dok grana 3 obuhvaća razumijevanje emocionalnih izraza, odnosa između emocija, između emocija i okolnosti te složene prijelaze između emocija. Grana 4 uključuje sposobnosti upravljanja emocijama. Iako se Upitnik emocionalne kompetentnosti (UEK-45, Takšić, 1998, 2002) temelji na ovom hijerarhijskom modelu, u kojem je EI definirana kao sposobnost, budući da se radi o upitniku samoprocjene, možemo reći da konceptualno ova mjera ipak pripada mjeri emocionalne inteligencije kao crte.

Upitnik je do sada korišten u velikom broju istraživanja i preveden na više od 10 svjetskih jezika (npr. Faria i sur., 2006), uglavnom na studentskoj populaciji i odraslim ispitanicima. Iako je UEK-45 korišten i u istraživanjima s adolescentima (Costa i Faria, 2016), ne postoji prilagođena i provjerena verzija upitnika koja bi bila primjerena djeci osnovnoškolske dobi.

Dosadašnja istraživanja povezivala su emocionalnu kompetentnost s različitim ponašajnim ishodima kod djece, poput agresivnog (Bohnert, Crnic i Lim, 2003) ili prosocijalnog ponašanja (Marquez, Martin i Brackett, 2006), depresivnosti i anksioznosti (Mohorić, Takšić i Šekuljica, 2016) te školskog uspjeha (Barchard, 2003).

U ranoj adolescenciji značajnije se razvija verbalno izražavanje te djevojčice i dječaci postaju sve uspješniji u opisivanju emocionalnih situacija, kao i vlastitih i tuđih emocija. Prema rezultatima istraživanja Cooka, Greenberga i Kuschea (1994) agresivnija djeca teže identificiraju i razumiju tuđe emocije u odnosu na manje agresivnu djecu. Također, lošija su u prepoznavanju uzroka pojedinih emocija, manje uče iz vlastitih emocionalnih iskustava, a često se u razumijevanju emocija oslanjaju na jednostavne i očite uzroke emocija (Bonhert i sur., 2003). Kada govorimo o prosocijalnom ponašanju, istraživanje koje su proveli Roberts i Strayer (1996) na djeci u dobi od 5, 9 i 13 godina pokazuje da su emocionalna ekspresivnost i emocionalni uvid, odnosno razumijevanje (što su sve komponente emocionalne kompetentnosti) značajni prediktori empatije, a empatija je značajan prediktor prosocijalnog ponašanja i kod djevojčica i kod dječaka. 
Iako se očekuje bolja povezanost testova maksimalnog učinka EI i školskog uspjeha, neki autori (npr. Saklofske, Austin i Minski, 2003) smatraju da i mjere samoprocjene EI mogu pridonijeti objašnjenju školskog uspjeha budući da i emocionalne i socijalne kompetencije te snalaženje u školskim situacijama također utječu na postignuće.

S obzirom na veliku važnost istraživanja emocionalnih aspekata dječjeg razvoja, nužno je razvijati provjerene mjere. Cilj je ovog rada jezično i sadržajno prilagoditi UEK-45 kako bi bio primjeren djeci te prikazati preliminarne rezultate adaptacije i validacije Upitnika emocionalne kompetentnosti za djecu.

\section{METODA}

\section{Sudionici}

Istraživanje je provedeno na prigodnom uzorku od $\mathrm{N}=171$ ( 85 djevojčica i 81 dječak; pet sudionika nije odgovorilo kojeg je spola) učenika viših razreda osnovne škole, u dobi od 11 do 15 godina $(\mathrm{M}=12,98 ; \mathrm{SD}=1,18)$. Uključeni su učenici iz triju osnovnih škola iz Rijeke i Rovinja.

Drugi uzorak uključivao je 277 učenika (141 djevojčica i 136 dječaka), učenika 5. i 6. razreda osnovne škole, u dobi od 10 do 13 godina $(M=11,47, S D=1,13)$.

\section{Instrumenti}

Upitnik emocionalne kompetentnosti za djecu (UEK-D) prilagođena je verzija Upitnika emocionalne kompetentnosti (UEK-45; Takšić, 2002). Sastoji se od tri podljestvice koje mjere sposobnosti Uočavanja i razumijevanja emocija, Izražavanja i imenovanja emocija te Regulacije i upravljanja emocijama. Čestice iz UEK45 jezično su prilagođene dobi rane adolescencije te je u malom pilot istraživanju nekoliko djece te dobi $(\mathrm{N}=5)$ ispunilo upitnik i dalo povratne informacije (npr. razumljivost pitanja, jasnoća jezika, prilagođenost sadržaja...).

Test rječnika emocija (TRE) (Takšić, Harambašić i Velemir, 2004) provjerava sposobnost imenovanja i razumijevanja emocija u zadanim riječima, odnosno sposobnost razumijevanja značenja koje prenose emocije. Test se sastoji od 35 podražajnih riječi (koje opisuju neko raspoloženje ili emociju), a ispitanici za svaku podražajnu riječ odabiru sinonim, od šest mogućih odgovora. Unutarnja konzistencija Testa rječnika emocija na ispitanom uzorku je zadovoljavajuća $(\alpha=0,87)$.

Test razumijevanja emocija (Mohorić, 2016) ispituje sposobnost razumijevanja emocija u opisanim situacijama. Sastoji se od opisa 28 situacija, a zadatak je sudionika procijeniti koju emociju će osjećati akter opisane situacije. Točan odgovor u 
testu određen je na temelju postavki Rosemanova modela emocija. U provedenom istraživanju test ima dobru pouzdanost unutarnje konzistencije $(\alpha=0,86)$.

Pridjevska mjera petofaktorskog modela ličnosti (Hudek-Knežević i sur., 2005) sastoji se od 25 pridjeva (npr. odgovoran, ljubazan) koji opisuju osobine ličnosti petofaktorskog modela. Svaka od pet osobina ličnosti opisana je s pet odgovarajućih pridjeva. U našem istraživanju dobiveni su nešto niži koeficijenti unutarnje konzistencije Cronbachov alfa od 0,58 (za skalu Ekstraverzija) do 0,78 (za skalu Neuroticizam).

Skala altruizma (Raboteg-Šarić, 2002) predstavlja mjeru tendencije altruističnog ponašanja u svakodnevnim životnim situacijama. Sastoji od 17 čestica koje sadrže opise prosocijalnih ponašanja u svakodnevnim situacijama, a zadatak je ispitanika da odgovori koliko se često ponašao na opisani način. Koeficijent pouzdanosti tipa unutarnje konzistentnosti na ispitanom uzorku jest zadovoljavajući i iznosi $\alpha=0,86$.

Upitnik agresivnog ponašanja (AG15; Keresteš, 1999) sastoji se od 15 čestica samoprocjene koje mjere proaktivnu agresivnost (npr. Volim udarati i ritati drugu djecu) i reaktivnu agresivnost (npr. Kad me netko udari, vratim mu istom mjerom). U provedenom istraživanju i podljestvice i ukupan rezultat imaju dobru pouzdanost tipa unutarnje konzistencije ( $\alpha_{\text {proag }}=0,85, \alpha_{\text {reag }}=0,85, \alpha_{\text {totalag }}=0,90$ ).

Školski uspjeh izračunat je kao prosjek triju ocjena (hrvatski jezik, engleski jezik i matematika) na polugodištu tekuće školske godine.

\section{POSTUPAK}

Sudjelovanje u istraživanju bilo je dobrovoljno i anonimno. Prikupljene su suglasnosti ravnatelja i stručnih suradnika, a zatim i potpisani informirani pristanci roditelja učenika. Učenici su ispunjavali upitnike samostalno, unutar pojedinog razrednog odjela, za vrijeme satova razredne zajednice. Ispunjavanje je trajalo između 30 i 45 minuta. Nakon završetka ispitivanja učenicima je objašnjena svrha ispitivanja i odgovoreno je na sva njihova pitanja, kako bi se otklonile eventualne nejasnoće ili sumnje.

\section{REZULTATI}

Svih 45 čestica Upitnika emocionalne kompetentnosti za djecu podvrgnuto je eksploratornoj faktorskoj analizi. Cilj je bio prilagoditi upitnik djeci tako da se zadrži trofaktorska struktura, uz što manji broj čestica. Indeks pogodnosti korelacijske matrice za faktorsku analizu KMO iznosio je 0,81 , uz značajan Bartlettov test sfericiteta $\left(\chi^{2}=3020,52, p<0,01\right)$. Metodom zajedničkih faktora, uz Kaiser-Gutmanov 
kriterij zadržavanja faktora, izlučeno je čak 12 faktora, međutim iz Scree plota jasno je vidljivo da se izdvaja 1 faktor s vrijednosti karakterističnog korijena od 11,75. Budući da originalni Upitnik emocionalne kompetentnosti za odrasle sadrži 3 podljestvice, ponovljena je analiza zajedničkih faktora uz forsiranu soluciju s tri faktora te kosokutnu (Oblimin) rotaciju. Zadržana tri faktora objasnila su 36\% varijance, uz vrijednosti karakterističnih korjenova 10,21, 8,36 i 2,99 (nakon rotacije). Međutim, određeni broj čestica remetio je jednostavnu strukturu, uz sadržajno nepoklapanja čestica i očekivanih faktora, $\mathrm{tj}$. podljestvica. U sljedećim su koracima iz faktorske analize isključena pitanja koja nisu sadržajno pripadala odgovarajućim faktorima te su imala niska i negativna zasićenja.

Budući da je cilj bio smanjiti broj čestica kako bi upitnik bio što primjereniji djeci, a da se pritom zadrži trofaktorska struktura, odlučeno je da u svakom faktoru ostane po 5 čestica (sadržajno najprimjerenijih i s najvišim zasićenjima na pripadajuće faktore). Provedena je konačna faktorska analiza na 15 čestica. Nakon što je provjereno da su zadovoljeni uvjeti za faktorizaciju (KMO iznosi 0,76, Bartlettov test sfericiteta je značajan, $\chi^{2}=866,514, \mathrm{p}<0,01$ ), provedena je analiza zajedničkih faktora uz fiksna tri faktora i kosokutnu (Oblimin) rotaciju. Faktori ukupno objašnjavaju 45,82\% varijance, uz vrijednosti karakterističnih korjenova 3,48, 3,29 i 2,53 (nakon rotacije).

Prema sadržanoj valjanosti prvi faktor nazvan je Izražavanje i imenovanje emocija, drugi Uočavanje i razumijevanje emocija i treći Regulacija i upravljanje emocijama. U odnosu na originalni UEK-45 koji provjerava koliko je osoba kompetentna u imenovanju, razumijevanju i regulaciji vlastitih, ali i tuđih emocija, Upitnik emocionalne kompetentnosti za djecu ispituje te sposobnosti ili samo u odnosu na vlastite emocije (Izražavanje i imenovanje emocija i Regulacija i upravljanje emocijama), ili u odnosu na one drugih ljudi (Uočavanje i razumijevanje emocija).

Dobivena faktorska struktura provjerena je na drugom uzorku ispitanika $(\mathrm{N}=$ 277). Odabranih 15 čestica analizirano je metodom zajedničkih faktora, uz kosokutnu (Oblimin) rotaciju. Tri izlučena faktora zajedno objašnjavaju 40,56\% zajedničke varijance, uz vrijednosti karakterističnih korjenova nakon rotacije od 3,40, 3,65 i 2,41. Čestice pokazuju očekivana zasićenja na odgovarajuće faktore. Iznimka je pitanje 10 (Kada sam dobre volje, čini mi se da sve mogu lako riješiti.) koje ima zasićenje na faktor 2 (Uočavanje i razumijevanje emocija), a prema sadržaju trebala bi pripadati faktoru 3; te pitanje 7 (Kada sam dobre volje, teško me rastužiti.) koje ima zasićenje na odgovarajući faktor nešto ispod $0,3(0,25)$. Rezultati obje faktorske analize prikazani su u Tablici 1 .

$\mathrm{Na}$ temelju provedene faktorske analize formirane su ljestvice, koje međusobno koreliraju od 0,36 do 0,48 (Tablica 2). Deskriptivni podaci prikazani su u Tablici 3. 
Tablica 1. Rezultati eksploratorne faktorske analize Upitnika emocionalne kompetentnosti za djecu metodom zajedničkih faktora uz Oblimin rotaciju za oba uzorka ispitanika

\begin{tabular}{|c|c|c|c|c|c|c|}
\hline & \multicolumn{3}{|c|}{ Faktor $(N=171)$} & \multicolumn{3}{|c|}{ Faktor $(N=277)$} \\
\hline & 1 & 2 & 3 & 1 & 2 & 3 \\
\hline Mogu lako opisati svoje osjećaje. & $\mathbf{0 , 8 9}$ & $-0,07$ & $-0,01$ & 0,79 & $-0,02$ & $-0,02$ \\
\hline Mogu lako opisati kako se sada osjećam. & $\mathbf{0 , 8 1}$ & 0,01 & $-0,01$ & 0,61 & 0,08 & 0,07 \\
\hline Mogu dobro pokazati svoje osjećaje. & 0,62 & 0,12 & 0,04 & 0,70 & 0,16 & $-0,06$ \\
\hline Znam kako se zovu skoro svi moji osjećaji. & 0,59 & 0,04 & 0,03 & $\mathbf{0 , 4 0}$ & $-0,01$ & 0,29 \\
\hline Mogu lako pokazati skoro sve svoje osjećaje. & $\mathbf{0 , 5 8}$ & 0,04 & 0,15 & 0,44 & 0,18 & 0,27 \\
\hline $\begin{array}{l}\text { Mogu vidjeti kada je nekom krivo zbog } \\
\text { nečega. }\end{array}$ & $-0,08$ & 0,79 & 0,12 & 0,12 & 0,49 & $-0,03$ \\
\hline Primijetim kada netko skriva osjećaje. & $-0,00$ & 0,76 & 0,10 & 0,03 & $\mathbf{0 , 5 8}$ & 0,03 \\
\hline $\begin{array}{l}\text { Primijetim kada se netko pravi da nije loše } \\
\text { volje. }\end{array}$ & 0,04 & 0,70 & $-0,03$ & $-0,02$ & 0,67 & $-0,06$ \\
\hline $\begin{array}{l}\text { Mogu vidjeti kada se netko ponaša drukčije } \\
\text { od onoga kako je raspoložen. }\end{array}$ & 0,16 & 0,67 & $-0,15$ & 0,01 & 0,67 & 0,06 \\
\hline Primjetim kada se netko osjeća bespomoćno. & 0,00 & 0,60 & 0,04 & 0,05 & 0,69 & $-0,07$ \\
\hline Kada sam dobre volje teško me rastužiti. & $-0,00$ & $-0,04$ & 0,66 & 0,17 & 0,13 & 0,25 \\
\hline $\begin{array}{l}\text { Kada sam dobre volje, čini mi se da sve } \\
\text { mogu lako riješiti. }\end{array}$ & $-0,12$ & 0,21 & 0,64 & 0,09 & 0,34 & 0,21 \\
\hline $\begin{array}{l}\text { I kada su svi oko mene loše volje, ja mogu } \\
\text { ostati dobre volje. }\end{array}$ & 0,14 & $-0,03$ & $\mathbf{0 , 4 3}$ & 0,07 & $-0,10$ & $\mathbf{0 , 5 8}$ \\
\hline $\begin{array}{l}\text { Mogu ostati dobro raspoložen/a i ako mi se } \\
\text { nešto ružno dogodi. }\end{array}$ & 0,08 & $-0,03$ & 0,41 & 0,17 & $-0,04$ & $\mathbf{0 , 5 0}$ \\
\hline Riješit ću i nešto jako teško iz inata. & 0,01 & 0,02 & 0,36 & $-0,13$ & 0,28 & 0,42 \\
\hline Vrijednosti karakterističnih korjenova & 3,48 & 3,29 & 2,53 & 3,40 & 3,35 & 2,41 \\
\hline
\end{tabular}

U prvom uzorku sve su testirane normalnosti raspodjele distribucija neznačajne, što znači da je zadovoljen uvjet normalnosti distribucije podljestvica i ukupnog rezultata, dok u drugom uzorku dvije podljestvice imaju distribuciju značajno ra-

Tablica 2. Koeficijenti korelacija između podljestvica Upitnika emocionalne kompetentnosti za djecu za oba uzorka ispitanika

\begin{tabular}{lcc}
\hline & $\begin{array}{c}\text { Uočavanje i razumijevanje } \\
\text { emocija }\end{array}$ & $\begin{array}{c}\text { Regulacija i upravljanje } \\
\text { emocijama }\end{array}$ \\
\hline Izražavanje i imenovanje emocija & 0,37 & 0,43 \\
& $(0,45)$ & $(0,48)$ \\
Uočavanje i razumijevanje emocija & & 0,36 \\
& & $(0,36)$ \\
\hline
\end{tabular}

* U zagradi su prikazani koeficijenti korelacije iz drugog uzorka $(N=277)$ 


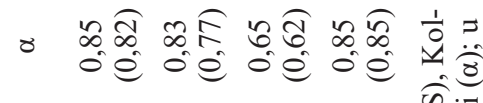

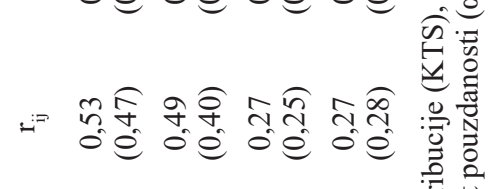

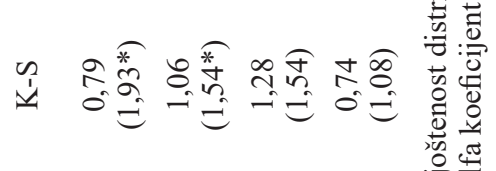

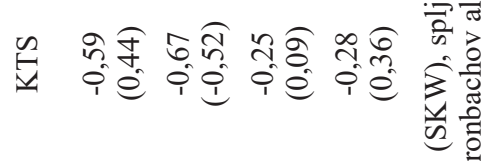

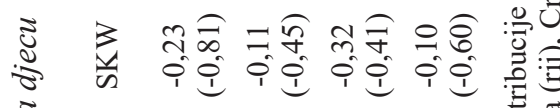

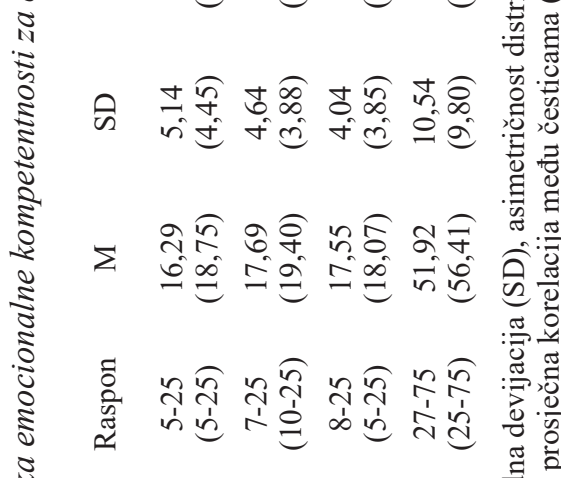

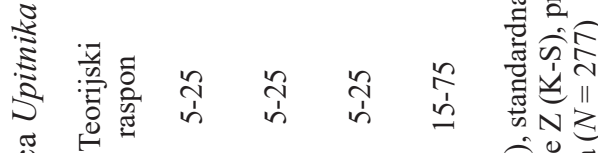

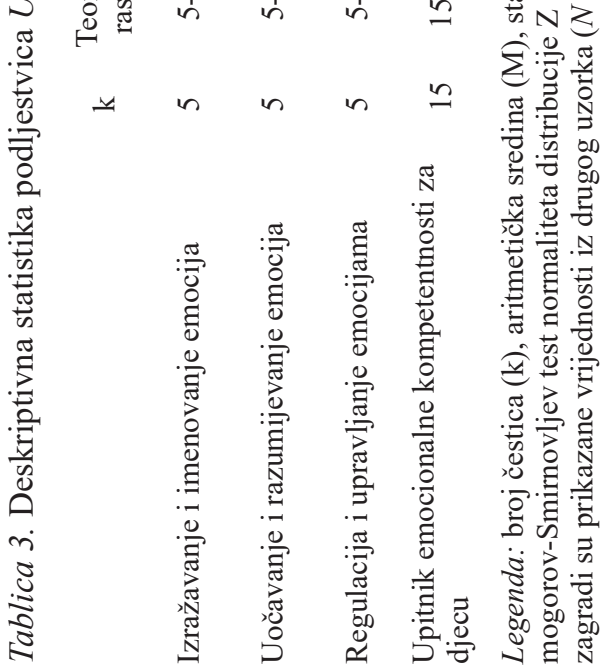




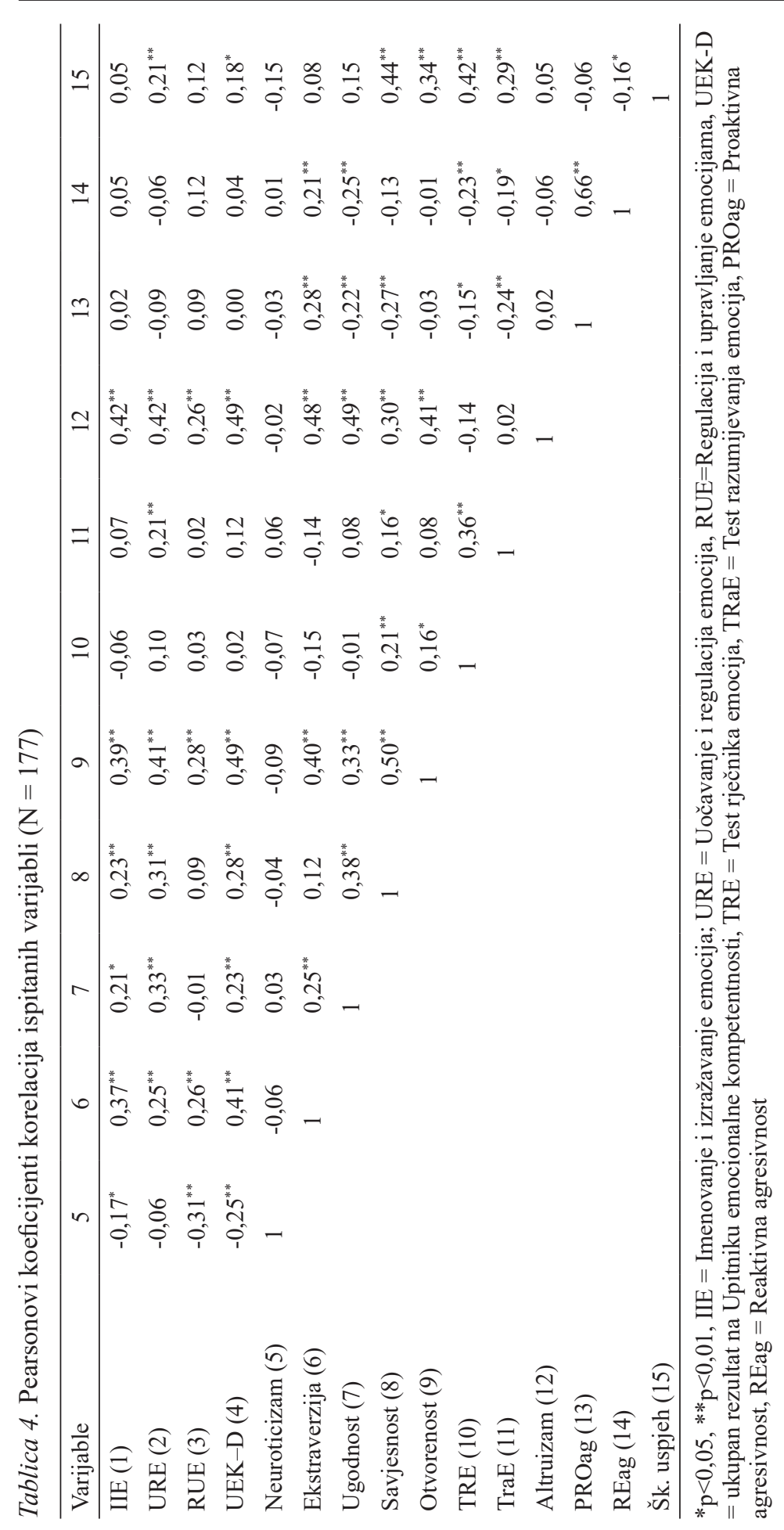


zličitu od normalne. Dobiveni koeficijenti unutarnje konzistencije Cronbachov alfa također su vrlo dobri (za podljestvice Izražavanje i imenovanje te Uočavanje i regulacija emocija i ukupan rezultat), dok je ta pouzdanost nešto niža za podljestvicu Regulacija i upravljanje emocijama. Niža pouzdanost ove podljestvice ne iznenađuje budući da se radi o najkompleksnijoj sposobnosti emocionalne inteligencije.

Provjerene su korelacije podljestvica i ukupnog rezultata s osobinama ličnosti, testovima sposobnosti EI, altruizmom i agresivnim ponašanjem te mjerom školskog uspjeha, na prvom uzorku ispitanika. Dobiveni koeficijenti korelacije prikazani su u Tablici 4.

Ukupan rezultat na Upitniku emocionalne kompetentnosti za djecu pokazuje umjerene korelacije s osobinama ličnosti iz modela velikih pet, koje se kreću od 0,23 (za Savjesnost) do 0,49 (za Otvorenost za iskustva), a slični rezultati su dobiveni i za podljestvice upitnika. Nisu dobivene korelacije s testovima sposobnosti emocionalne inteligencije, osim korelacije podljestvice Uočavanja i razumijevanja emocija s Testom razumijevanja emocija. Od odabranih kriterijskih mjera, i podljestvice i ukupan rezultat imaju značajne i umjereno visoke korelacije s altruizmom, dok ne postoje korelacije $s$ agresivnim ponašanjem. Uočavanje i razumijevanje emocija, kao i ukupan rezultat na upitniku u značajnoj su korelaciji i s mjerom školskog uspjeha.

Provjerene su i spolne razlike na podljestvicama i ukupnom rezultatu na Upitniku emocionalne kompetentnosti za djecu. Jedina značajna razlika dobivena je na podljestvici Uočavanje i razumijevanje emocija, na kojoj djevojčice postižu značajno više rezultate $\mathrm{u}$ odnosu na dječake $\left(\mathrm{M}_{\text {djevojëice }}=18,58, \mathrm{M}_{\text {dječaci }}=16,77 ; \mathrm{t}=2,45\right.$, $\mathrm{p}<0,05)$.

\section{RASPRAVA}

Cilj je istraživanja bio prilagoditi i validirati Upitnik emocionalne kompetentnosti za djecu, uz zadržavanje originalne trofaktorske strukture. Konačna verzija Upitnika emocionalne kompetentnosti za djecu sadrži 15 pitanja, po pet za svaku podljestvicu. Podljestvice mjere sposobnosti izražavanja i imenovanja (svojih) emocija, uočavanja i razumijevanja (tuđih) emocija te regulacije i upravljanja (vlastitim) emocijama. Prisutna su manja odstupanja u odnosu na originalnu verziju upitnika, koji procjenjuje sposobnosti izražavanja, razumijevanja i regulacije vlastitih, ali i tuđih emocija. Zbog nužnosti skraćivanja upitnika, a da se pritom ipak obuhvate sve tri sposobnosti iz domene emocionalne inteligencije, Upitnik emocionalne kompetentnosti za djecu provjerava samo izražavanje i regulaciju vlastitih (ali ne i tuđih) emocija te razumijevanje tuđih (ali ne i vlastitih) emocija. U budućnosti bi svakako trebalo razmotriti može li se daljnjim dodavanjem odgovarajućih čestica ispitati i ove preostale aspekte emocionalne kompetentnosti. 
Podljestvica Regulacija i upravljanje emocijama ima nešto nižu pouzdanost, dok su ostale pouzdanosti dobre. Slična pouzdanost te podljestvice dobije se i za originalni upitnik UEK-45 (za odrasle), uz pouzdanost od 0,67 do 0,78 (Takšić, 1998). Niža pouzdanost vjerojatno je posljedica malog broja pitanja kojima se nastoji ispitati složena sposobnost regulacije emocija. Tako se od pet pitanja, tri odnose na sposobnost zadržavanja dobrog raspoloženja, dok se preostala dva odnose na pozitivan učinak emocija na mišljenje/ponašanje. Sposobnost regulacije emocija izuzetno je važna u djetetovu životu. Djeca koja su uspješnija u upravljanju svojim (i tuđim) emocijama pažljivija su, više se trude i postižu bolji školski uspjeh. Također, uspješnija su u rješavanju konflikata s vršnjacima, iskazuje manje simptoma psihološkog stresa te su bolja u uspostavljanju socijalnih odnosa s vršnjacima (Zeman, Cassano, Perry-Parrish i Stegall, 2006).

Nisu dobivene značajne povezanosti upitnika emocionalne kompetentnosti za djecu i testa rječnika emocija te testa razumijevanja emocija. Rezultati su u skladu $\mathrm{s}$ istraživanjima koja govore da mjere samoprocjene i mjere sposobnosti proizlaze iz potpuno različitih konceptualizacija emocionalne inteligencije te da se ne očekuje povezanost između rezultata na tim mjerama ili da će ta povezanost biti vrlo niska (Warwick i Nettelbeck, 2004). U našem istraživanju jedina pozitivna korelacija dobivena je između rezultata na podljestvici Uočavanje i razumijevanje emocija $\mathrm{i}$ rezultata na Testu razumijevanja emocija, što bi značilo da učenici koji procjenjuju da mogu prepoznati kako se netko osjeća ujedno i općenito bolje razumiju koje emocije će se javiti u određenoj situaciji. Mogući razlog nepovezanosti je i prilagođenost mjernih instrumenata djeci ove dobi. Iako je Test razumijevanja emocija razvijen za djecu osnovnoškolske dobi (Mohorić, 2016), Test rječnika emocija (iako već korišten u istraživanjima na ovoj populaciji), moguće je pretežak te stoga ne može dovoljno dobro diferencirati učenike s obzirom na njihovo poznavanje emocionalnih izraza i riječi.

Od osobina ličnosti, emocionalna kompetentnost najviše je povezana s otvorenošću, zatim s ekstraverzijom, nešto niže je povezana sa savjesnošću i ugodnosti, dok je prema očekivanjima veza emocionalne kompetentnosti i neuroticizma negativna. Slični rezultati dobiveni su i u meta-analizi van Rooya i Viwesvarena (2004), koji pronalaze male do umjerene korelacije između EI i osobina ličnosti.

Emocionalna kompetencija pozitivno je povezana s altruističnim ponašanjem. Petrides, Sangareau, Furnham i Frederickson (2006) u svojem istraživanju pronalaze da su učenici koji se procjenjuju višima na skalama emocionalne inteligencije procijenjeni od strane drugih (nastavnika i vršnjaka) kao više sklona prosocijalnom ponašanju te manje sklona agresivnom ponašanju. Nije pronađena povezanost između emocionalne kompetentnosti i agresivnog ponašanja, iako istraživanja potvrđuju povezanost između ovih dviju mjera (Babić Čikeš, 2017).

Uočavanje i razumijevanje emocija, kao i ukupna razina emocionalne kompetentnosti, značajno su, iako vrlo nisko, povezane sa školskim uspjehom. Budući da je istraživanje provedeno u drugom polugodištu te da se na kraju prvog polugodišta 
ne zaključuju ocjene, školski uspjeh je posredno izračunat kao prosjek ocjena na polugodištu iz triju predmeta (hrvatski jezik, engleski jezik i matematika). Bolji uspjeh postižu oni učenici koji bolje uočavaju i razumiju tuđe emocije te koji se procjenjuju emocionalno kompetentnijima. Pretpostavka je da će se takvi učenici moći bolje prilagoditi izazovnim situacijama u školskom okruženju, što će na neki način olakšati i postizanje boljih ocjena.

Provjerene su i razlike između dječaka i djevojčica u emocionalnoj kompetentnosti. Djevojčice postižu značajno više rezultate u odnosu na dječake na skali uočavanja i razumijevanja emocija, što se u skladu s prijašnjim rezultatima istraživanja prema kojima su žene uspješnije od muškaraca na sposobnostima emocionalne inteligencije (Extremera, Fernandez-Berrocal i Salovey, 2006). Sposobnost razumijevanja emocija najsličnija je empatiji i emocionalnoj osjetljivosti, koje su također više izražene kod djevojčica (Rose i Rudolph, 2006.)

Nekoliko je ograničenja ovog istraživanja. Iako je trofaktorska struktura upitnika provjerena na dva odvojena uzorka, budući da se radi o provjeri latentne strukture već poznatog mjernog instrumenta, konfirmatorna analiza bila bi primjerenija. Stoga se u sljedećim koracima razvoja Upitnika emocionalne kompetentnosti za djecu planira sadržajno doraditi upitnik, kako bi uključilo više aspekata emocionalne inteligencije te daljnja provjera strukture konfirmatornom faktorskom analizom.

Zaključno, Upitnik emocionalne kompetentnosti za djecu zadržao je originalnu trofaktorsku strukturu, uz dobru sadržajnu valjanost i pouzdanost (osim za podljestvicu Regulacija i upravljanje emocijama). Konvergentno-divergentna valjanost je također zadovoljavajuća, uz očekivano najvišu korelaciju s Otvorenošću iz modela velikih pet i nisku korelaciju s Testom razumijevanja emocija. Što se tiče kriterijske valjanosti, značajno je povezana s altruističnim ponašanjem te sa školskim uspjehom (iako vrlo nisko), a nije dobivena povezanost s agresivnim ponašanjem, iako se prema dosadašnjim istraživanjima takva povezanost očekuje.

\section{LITERATURA}

Babić Čikeš, A. (2017). Emocionalna inteligencija i agresivno ponašanje u djetinjstvu i adolescenciji - pregled istraživanja. Psihologijske teme, 26, 283-308.

Barchard, K.A. (2003). Does Emotional Intelligence Assist in the Prediction of Academic Success? Educational and Psychological Measurement, 63, 840-858.

Bohnert, A.M., Crnic, K.A. i Lim, K.G. (2003). Emotional competence and aggressive behaviour in school-age children. Journal of Abnormal Child Psychology, 31, 79-91.

Cook, E., Greenberg, M. i Kusche, C. (1994). The relations between emotional understanding, intellectual functioning, and disruptive behavior problems in elementary schoolaged children. Journal of Abnormal Psychology, 22, 205-219.

Costa, A. i Faria, L. (2016). Emotional intelligence throughout Portuguese secondary school: a longitudinal study comparing performance and self-report measures. European Journal of Psychology of Education, 31, 419-437. 
Extremera, N., Fernandez-Berrocal, P. i Salovey, P. (2006). Spanish version of the MayerSalovey-Caruso Emotional Intelligence Test (MSCEIT). Version 2.0: reliabilities, age and gender differences. Psicothema, 18, 42-48.

Faria, L., Lima Santos, N., Takšić, V., Räty, H., Molander, B., Holmström, S. i Toyota, H. (2006). Cross-cultural validation of the Emotional Skills and Competence Questionnaire (ESCQ). Psicologia, 20, 95-127.

Hudek-Knežević, J., Kardum, I. i Kalebić-Maglica, B. (2005). The source of stress and coping styles as mediators and moderators of the relationship between personality traits and physical symptoms. Review of Psychology, 12, 91-101.

Keresteš, G. (1999). Agresivno i prosocijalno ponašanje školske djece u kontekstu ratnih zbivanja: Provjera posredujućeg utjecaja roditeljskog ponašanja. Neobjavljena doktorska disertacija. Sveučilište u Zagrebu.

Marquez, P.G., Martin, R.M. i Brackett, M.A. (2006). Relating emotional intelligence to social competence and academic achievement in high school students. Psicothema, 18, 118-123.

Mayer, J. D. i Salovey, P. (1997). What is emotional intelligence? U P. Salovey i D. Sluyter (ur.), Emotional development and emotional intelligence: Educational implications (str. 3-31). New York: Basic Books.

Mohorić, T. (2016). Konstrukcija i validacija Testa razumijevanja emocija u okviru Rosemanova modela emocija. Psihologijske teme, 25, 223-243.

Mohorić. T., Takšić, V. i Šekuljica, D. (2016). Uloga razumijevanja emocija u razvoju simptoma depresivnosti i anksioznosti u ranoj adolescenciji. Socijalna psihijatrija, 44, 4658.

Petrides, K. V., Pita, R. i Kokkinaki, F. (2007). The location of trait emotional intelligence in personality factor space. British Journal of Psychology, 98, 273-289.

Petrides, K.V., Sangareau, Y., Furnham, A. i Frederickson, N. (2006). Trait Emotional Intelligence and Children's Peer Relations at School. Social Development, 15, 537-547.

Raboteg-Šarić, Z. (2002). Skala altruizma. U K. Lacković-Grgin, A. Proroković, V. Ćubela i Z. Penezić (ur), Zbirka psihologijskih skala i upitnika (str. 87-92). Zadar: Filozofski fakultet.

Roberts, W. i Strayer, J. (1996). Empathy, emotional expressiveness and prosocial behavior. Child Development, 67, 449-470.

Rose, A.J. i Rudolph, K.D. (2006). A Review of Sex Differences in Peer Relationship Processes: Potential Trade-offs for the Emotional and Behavioral Development of Girls and Boys. Psychological Bulletin, 132, 98-131.

Saarni, C. (1999). The development of emotional competence. New York: Guilford Press.

Saklofske, D.H, Austin, E.J. i Minski, P.S. (2003). Factor structure and validity of a trait emotional intelligence measure. Personality and Individual Differences, 34, 707-721.

Takšić, V. (1998). Validacija konstrukta emocionalne inteligencije. Neobjavljena doktorska disertacija, Sveučilište u Zagrebu.

Takšić, V. (2002). The importance of emotional intelligence (competence) in positive psychology. Rad prezentiran na the First International Positive Psychology Summit, Washington, DC, 4-6.10.2002.

Takšić, V., Harambašić, D. i Velemir, B. (2004). Emotional Vocabulary Test as an attempt to 
measure the emotional intelligence ability - understanding emotion aspect. Rad prezentiran na 28th International Congress of Psychology, Beijing, 08-13.08.2004.

Zeman, J., Cassano, M., Perry-Parrish, C. i Stegall, S. (2006). Emotion regulation in children and adolescence. Developmental and Behavioral Pediatrics, 27, 155-168.

van Rooy, D. L. i Viswesvaran, C. (2004). Emotional intelligence: A meta-analytic investigation of predictive validity and nomological net. Journal of Vocational Behaviour, $65,71-95$.

Warwick, J., Nettelbeck, T. (2004). Emotional intelligence is ... ? Personality and Individual Differences, 37, 1091-1100.

\title{
EMOTIONAL SKILLS AND COMPETENCE QUESTIONNAIRE FOR CHILDREN (ESCQ-C) - PRELIMINARY ADAPTATION AND VALIDATION RESULTS
}

\begin{abstract}
Emotional Skills and Competence Questionnaire (ESCQ-45, Takšić, 1998, 2002) was developed using the hierarchical model of emotional intelligence, which defines EI as an ability to perceive and express emotions, integrate emotions in thoughts, understand emotions, and to manage and regulate emotions. The ESCQ-45 was used in a large number of studies and has shown satisfactory psychometric characteristics. It was translated and validated in over 10 languages. Since emotional aspects of children's development are very important, we need psychometrically sound and verified instruments. This research represents the first step in the adaptation and validation of the ESCQ for children. Questionnaires were administered to 171 elementary schools students (age $11-15$ ), and to 277 students (grades 5 and 6), in three city schools in Rijeka and Rovinj. The ESCQ-C kept the original three-factor structure, along with good content validity and reliability coefficients (only borderline reliability coefficient was obtained for the Manage and Regulate emotions subscale). The ESCQ-C had moderate correlations with the Big Five personality traits. It was also significantly correlated with altruistic behavior and school success (although very low). Although expected, there was no significant correlation between the ESCQ-C and aggressive behavior. The ESCQ-C was linguistically adapted for children, with a reduced number of items. Further improvement of the content of ESCQ-C is needed, so the scale can include more aspects of EI, and especially to improve characteristics of the Manage and Regulate emotions subscale.
\end{abstract}

Key words: emotional competences, ESCQ-C, early adolescence, Big Five personality traits 
